PINJAMAN KREDIT DALAM PERSPEKTIF PENDIDIKAN ISLAM

\title{
Ahmad Abdullah
}

Prodi Pendidikan Agama Islam Unismuh Makassar || emai: $\underline{\text { daiahmad@ @yahoo.co.id }}$

\begin{abstract}
Abstrak
Tujuan penulisan ini untuk mengungkap sistem perkreditan yang ada dan berlaku saat ini. Metode yang digunakan yaitu pengkajian terhadap Al-Qur'an dan Hadis tentang riba beserta teori-teori pelarangannya. Melalui pengkajian tersebut, praktik perekonomian yang sesuai syari'at secara konsep dapat dirumuskan, khusunya dalam pembiayaan dengan sistem jual-beli. Hasil dari pembahasan ini menunjukkan bahwa hukum dasar dari jual-beli secara kredit dibolehkan. Syaikh Ibnu Utsaimin Berkata: Menjual dengan kredit artinya bahwa sesorang Menjual sesuatu (barang) dengan harga tangguh yang di lunasi secara berjangka hukum aslinya adalah di bolehkan berdasarkan firman Allah QS. Al-Baqarah: 282. Demikian pula Nabi Muhammad Saw. membolehkan jual beli as-Salam, yaitu membeli secara kredit terhadap barang yang dijual.
\end{abstract}

Kata Kunci: Islam, Pinjaman Kredit 


\begin{abstract}
The purpose of this paper is to uncover the existing and current credit system. The method used is the study of the Qur'an and Hadith about usury along with its prohibition theories. Through these studies, economic practices that are in accordance with the shari'ah in concept can be formulated, especially in financing with a buying and selling system. The results of this discussion indicate that the basic law of buying and selling on credit is permissible. Shaykh Ibnu Utsaimin Said: Selling with credit means that someone selling something (goods) with a strong price that is repaid in full the original law is allowed based on the word of Allah QS. Al-Baqarah: 282. Likewise the Prophet Muhammad Saw. allowed the sale of as-Salam, which is to buy on credit for goods sold.
\end{abstract}

Keywords: Islam, Credit Loans

\section{PENDAHULUAN}

Dunia yang semakin modern seperti saat ini, kebutuhan suatu barang dalam kehidupan manusia semakin tak terbatas menuntut setiap individu harus memilikinya. Pola konsumtif masyarakat modern seperti saat ini tidak diimbangi dengan pendapatan perkapita masing-masing individu. Oleh sebab itu perbankan di Indonesia dan negaranegara lain khususnya bank konvensional dan lembaga keuangan lainnya (non bank) memberikan kemudahan kepada setiap elemen masyarakat dalam pembiayaan berupa pembelian barang dan peminjaman uang dalam bentuk kredit.

Kredit dalam Islam disebut dengan pembiayaan, menurut UU Perbankan No. 10 Tahun 1998 pengertian pembiayaan adalah penyediaan uang atau tagihan yang dapat dipersamakan dengan itu, berdasarkan persetujuan atau kesepakatan antara bank dengan pihak lainnya yang mewajibkan pihak yang dibiayai untuk mengembalikan uang atau tagihan tersebut setelah jangka waktu tertentu dengan imbalan atau bagi hasil.

Pembicaraan tentang perkreditan, terkhusus yang dilakukan oleh lembagalembaga keuangan melalui pemberian pemibayaan dengan sistem jual-beli, menemui banyak perselisihan. Hal tersebut disebabkan oleh sistem jual beli yang diterapkan mengandung unsur riba, sedangkan riba merupakan salah satu dosa besar.

Di Samping itu, tentu masingmasing pihak ingin meraih keuntungan. Akan tetapi secara objektif keuntungan yang diperoleh dalam perdagangan tidak pernah, melainkan senantiasa 
berubah-ubah setiap waktu apalagi pemberian kredit dalam bentuk rupiah perekonomian negara kurang stabil. maupun valuta asing kepada pihak Berawal dari hal tersebut maka penulis ketiga serta pembelian surat akan mengungkap sistem perkreditan berharga.Sedangkan dalam terminologi yang ada dan berlaku saat ini.

\section{PEMBAHASAN}

\section{Pengertian Kredit}

Ada beberapa pendapat yang menjelaskan tentang pengertian kredit, antara lain: Menurut Pasal 1 (11) UU No. 10/1998, menjelaskan bahwa Kredit adalah penyediaan uang atau tagihan yang dapat dipersamakan dengan itu, berdasarkan persetujuan atau kesepakatan pinjam meminjam antara bank dengan pihak lain yang mewajibkan pihak peminjam untuk melunasi utangnya setelah jangka waktu tertentu dengan pemberian bunga.

Menurut Thomas Suyatno, 1998, menjelaskan bahwa Kredit adalah penyediaan uang, atau tagihan-tagihan yang dapat disamakan dengan itu berdasarkan persetujuan pinjammeminjam antara bank dan lain pihak dalam hal, pihak peminjam berkewajiban untuk mengembalikan sejumlah uang yang dipinjam beserta bunganya sesuai dengan kesepakatan. Sedangkan pendapat lain menyatakan kredit bank adalah semua realisasi
Indonesia, kredit diartikan sebagai pinjaman uang dengan pembayaran pengembalian secara mengangsur.

\section{Macam-Macam Pinjaman Kredit}

Landasan Hukum Bunga Bank

Secara leksikal, bunga sebagai terjemahan dari kata interest. Secara istilah sebagaimana diungkapkan dalam suatu kamus dinyatakan, bahwa "interest is a charge for a financial loan, usually a percentage of the amount loaned". Bunga adalah tanggungan pada pinjaman uang, yang biasanya dinyatakan dengan presentase dari uang yang dipinjamkan. Pendapat lain menyatakan "interest yaitu sejumlah uang yang dibayar atau dikalkulasi untuk penggunaan modal. Jumlah tersebut misalnya dinyatakan degan satu tingkat atau presentase modal yang bersangkut paut dengan itu yang sekarang sering dikenal dengan suku bunga modal“ (Muhammad, 2000).

Ada yang memebedakan antara riba dan rente (bunga) seperti Mohammad Hatta. Mantan Wakil 
Presiden RI, sebagaimana dikutip oleh Masjfuk Zuhdi, menerangkan bahwa riba adalah untuk pinjaman yang bersifat kosumtif, sedangkan rente adalah untuk pinjaman yang bersifat produktif, demikian pula istilah usury dan interest, bahwa usury ialah bunga pinjaman yang sangat tinggi, sehingga melampaui suku bunga yang diperbolehkan oleh hukum. Sedangkan interest ialah bunga pinjaman yang relatif rendah. Tetapi dalam realitas atau praktek menurut Maulana Muhammad Ali adalah sukar untuk membedahkan antara usury dan interest, sebab pada hakekatnya kedua-keduanya memberatkan bagi para peminjam (Zuhdi, 1998).

Oleh karena itu, apabila menarik pelajaran sejarah masyarakat Barat, terlihat jelas bahwa "interest" dan "usury" yang telah dikenal saat ini pada hakikatnya adalah sama. Keduanya berarti tambahan uang, umumnya dalam prosentase. Istilah usury muncul karena belum mapannya pasar keuangan pada zaman itu sehingga penguasa harus menetapkan suatu tingkat bunga yang dianggap wajar. Namun setelah mapannya lembaga dan pasar keuangan, kedua istilah itu menjadi hilang karena hanya ada satu tingkat bunga di pasar yang sesuai dengan hukum permintaan dan penawaran (Muhammad, 2000).

Berbicara mengenai bunga bank, maka tidak bisa lepas dari yang kata riba. Kata riba berasal dari bahasa Arab yang secara etimologis berarti "tambahan (az-Ziyadah)" (Nasution, 1996) atau "kelebihan" (Zuhdi, 1998), yakni tambahan pemabayaran atas uang pokok d pinjaman. Ada pendapat lain yang mengatakan bahwa riba merupakan kelebihan sepihak yang dilakukan oleh salah satu dari orang yang sedang bertransaksi.

Berdasarkan pandangan sebagian mufassir, kata sandang (definite article alif lam), berarti menunjuk kasus tertentu (ma'rifah). Maka makna kata arriba yang dimaksud adalah praktek pengambilan untung dari debitur yang sudah biasa di kalangan orang-orang Arab pra-Islam ketika al-Qur'an belum diturunkan, dengan pemahaman ini, kesimpulan awal yang barangkali sangat penting untuk dicatat, bahwa untuk bias memahami ayat secara lebih tepat dan mengena, seorang harus mengetahui sebab-sebab yang melatarbelakangi turunnya ayat (asbab an-Nuzul), barulah kemudian dapat 
diketahui apa arti riba sebenarnya (Nasution, 1996).

Oleh karena itu, pengertian riba menurut terminologi (pendapat ulama) adalah bunga kredit yang harus diberikan oleh orang yang berhutang kepada orang yang berpiutang, sebagai imbalan untuk menggunakan sejumlah uang milik berpiutang dalam jangka waktu yang telah ditetapkan (As Sabuni, 1972). Misalnya si A memberi pinjaman pada si B dengan syarat si B harus mengembalikan uang pokok pinjaman serta sekian persen tambahannya. Di dalam al-Qur'an dan as-Sunnah terdapat beberapa ayat yang membicarakan riba secara eksplisit di antaranya adalah:

Firman Allah SWT dalam QS. Ali Imran (30): 130

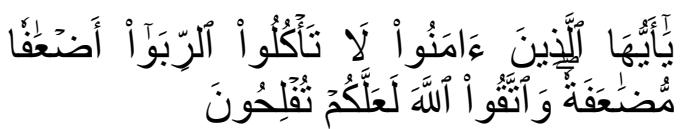

Hadis Nabi SAW:

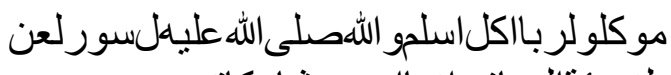

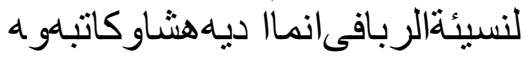

Dari beberapa ayat dan hadis yang telah disebutkan tadi jelaslah bahwa riba itu betul-betul dilarang dalam agama Islam. Muncul sebuah pertanyaan, apakah semua riba termasuk dalam katagori arti atau maksud dari ayat dan hadits di atas?. Jawaban dari pertanyaan tersebut adalah ada beberapa pendapat dari para ulama. Di sini dijelaskan riba nasi'ah dilarang karena ayat tersebut diturunkan karenanya (kejadian di masa jahiliyah). Jadi, dengan kata lain, turunnya ayat itu karena adanya riba nasi'ah. Menurut Ibnu Qayyim dalam kitab 'Ilami al-Muwaqi' in, sebagaimana dikutip Sulaiman Rasjid, mengatakan, bahwa "riba nasi'ah adalah riba yang dilakukan oleh kaum jahili di masa jahiliyah. Mereka menta-khirkan utang dari waktu yang semestinya dengan menambah

\section{Pengertian Bunga/Riba}

Secara etimologis, kata "ar-riba" bermakna zada wana nama', yang berarti bertambah dan bertumbuh (Abadi, 1998: 332). Didalam Al-quran, kata ar-riba berserta berbagai bentuk derivasinya disebut sebanyak 20 kali, 8 diantaranya berbentuk kata riba itu sendiri. Kata ini digunakan dalam alquran dengan bermacam-macam arti, seperti tumbuh, tambah, menuyuburkan, mengembang dan menjadi besar dan banyak.

Riba secara umum didefenisikan sebagai melebihkan keuntungan (harta) dari salah mdengan tanpa memberikan 
imbalan terhadap kelebihan tersebut. nasi'ah (sebagaimana defenisi kedua). (al-Jaziri, 1972 :221). Dalam ungkapan Namun, Abu Zahra dan Rafiq Yunus alyang lain, riba dipahami sebagai Misrih membuat pembagaian riba yang pembayaran utang yang harus dilunasi agak berbeda dengan ulama lainnya. oleh orang yang berutang lebih besar Menurut keduanya, riba dibedakan atas daripada jumlah pinjamannya sebagai riba yang terjadi pada utang piutang imbalan terhadap tenggang waktu yang yang disebut dengan riba nasi'ah dan telah lewat waktu (Muslim, $2005: 128$ ).

riba yang terjadi pada jual beli, yaitu

Dengan mengabaikan perbedaan riba nasa' dan riba fadl. Al-misrih pendapat yang ada, umumnya para menekankan pentingnya pembedaan fuqabah' menyepakati akan adanya dua antara riba nasia'ah dengan riba nasa' macam riba, yaitu riba fadl agar terhindar dari kekeliruan dalam (sebagaimana definisi pertama) dan riba mengidentifikasi berbagai bentuk riba.

Tabel 1

Pembagian Riba Berdasarkan Transaksi

\begin{tabular}{|c|c|c|c|c|}
\hline \multirow{4}{*}{ Riba } & Transaksi & Jenis & Unsur-Unsur & Keterangan \\
\cline { 2 - 5 } & $\begin{array}{c}\text { Pinjam- } \\
\text { meminjam }\end{array}$ & RibaNasi'ah & $\begin{array}{c}\text { Penundaan dan } \\
\text { Tambahan }\end{array}$ & $\begin{array}{c}\text { Sepakat tentang } \\
\text { haramnya jika } \\
\text { dzulm dan } \\
\text { ekspoitatif }\end{array}$ \\
\cline { 2 - 4 } & Jual Beli & Riba Nasa' & Penundaan & Masih Ikhtilaf \\
\cline { 2 - 4 } & Riba Fadl & Tambahan & Mand \\
\hline
\end{tabular}

Riba nasi'ah dalam defenisi perbincangkan mengenai bunga bank sebagaimana yang di praktikkan (interes). Sementara pada riba fadl masyarakat arab jahiliyyah dengan ciri masih di perdebatkan hukumnya di utama berlipat ganda dan eksploitatif antara ulama dan cendekiawan muslim. telah disepakati keharamannya oleh Hassan merupakan salah satu ulama para ulama. Sementara yang kini yang tidak setuju dengan menjadi perdebatan adalah riba nasi'ah pengharamannya dengan berbagai yang beripat ganda dan dalam taraf alasan (Ridha, $137 \mathrm{H}:$ 113-114). tertentu di pandang tidak eksploitatif, Perhatikan tabel berikut ini! sebagaimana yang banyak di 
Tabel 2

Pembagian Riba Berdasarkan Illat Hukumnya

\begin{tabular}{|c|l|l|}
\hline \multicolumn{1}{|c|}{ Riba } & \multicolumn{1}{|c|}{ Illat Hukumnya } & \multicolumn{1}{c|}{$\begin{array}{c}\text { Cara Transaksi dan } \\
\text { Jenis Barangnya }\end{array}$} \\
\hline Riba nasi'ab & Modernis : Dzulm (kezaliman) & Pinjam uang \\
\cline { 2 - 3 } & Neo-Revivalisme : Ziyadah (tambahan) & Pinjam uang \\
\hline \multirow{5}{*}{ Riba Fadh } & $\begin{array}{l}\text { Abu Hanifah : Setimbang (ittihad al- } \\
\text { kail) Imam Malik, Syafi'i dan Ahmad : } \\
\text { sejenis dalam harga }\end{array}$ & $\begin{array}{l}\text { Tukar (beli) emas dan } \\
\text { perak }\end{array}$ \\
\cline { 2 - 3 } & $\begin{array}{l}\text { Abu hanifah : seukuran (ittihad al- } \\
\text { kail)Iman Malik : sejenis (ittihad al- } \\
\text { jins) dan termaksud makanan } \\
\text { Ahmad : makanan dengan syarat bisa } \\
\text { ditimbang dan diukur }\end{array}$ & $\begin{array}{l}\text { Tukar (beli) gandum, } \\
\text { kurma, garam }\end{array}$ \\
\hline
\end{tabular}

\section{Larangan Riba}

Pelarangan riba dalam Al-Qur'an diturunkan tidak sekaligus melainkan ditunrakan dalam 4 tahap. Tahap-tahap pelanggaran riba dalam Al-Qur'an sebagai berikut: Tahap pertama, menolak anggapan bahwa peranan riba yang dapat desahirnya eolah-olah menolong mereka yang memerlukannya sebagai perbuatan taqaruf (mendekatkan diri) kepada Allah (Qs. Ar-Rum: 39). Tahap kedua, riba digambarkan sebagai sesuatau yang buruk Allah SWT mengancam akan memberi alasan yang keras kepala orang yahudi yang memakan riba (Qs. AnNisa: 160-169). Tahap ketiga, larangan riba dengan dikaitkan pada suatu tambahan yang berlipat ganda (Qs. AlImran: 130). Ayat ini turun setelah perang uhud, yaitu tahun ketiga hijriyah.

Menurut Antonio (2001: 49), istilah berlipat ganda harus di pahami sebgai sifat bukan syarat sehingga pengertiannya adalah yang di harapkan bukan hanya yang berlipat ganda saja sementara yang sedikit, maka tidak haram, melainkan sifat riba yang berlaku umum pada waktu itu adalah berlipat ganda. Tahap keempat, merupkan tahap terakhir dimana Alaah dengan tegas dan jelas mengharamkan apapun jenis tambahan yang di ambil dan di pinjam (Qs. Al-Baqarah: 278279) .

\section{Ekonomi Islam}

Menurut bahasa, ekonomi Islam (syariah) terdiri dari dua kata yaitu ekonomi dan Islam.Kata "ekonomi", 
berarti perihal pengurus dan mengatur kemakmuran, dan sebagainya. Dan kata "syari'ah", yaitu hukum atau undangundang yang ditentukan Allah swt. untuk hamba-Nya sebagaimana terkandung dalam Kitab Suci Al-Qur'an dan diterangkan oleh Rasulullah dalam bentuk sunnahnya. Jadi ekonomi syari'ah adalah ekonomi atau perihal yang mengurus dan mengatur kemakmuran berdasarkan agama atau aturan-aturan yang telah disyariatkan oleh Islam, atau pengaturan kemakmuran berdasarkan prinsip ekonomi dalam Islam.

Menurut istilah, ekonomi Islam menurut Muhammad Abdul Mannan, ialah: Ekonomi Islam merupakan ilmu pengetahuan sosial yang mempelajari masalah-masalah ekonomi rakyat yang diilhami oleh nilai-nilai Islam. Dengan demikian dapat dipahami bahwa ekonomi Islam adalah, perihal mengenai ekonomi atau mengurus dan mengatur kemakmuran dengan berlandaskan pada nilai-nilai Islam.

\section{Landasan Hukum Ekonomi Islam}

Menurut Al-Qur'an

a. Pengertian Al-Qur'an dan Periode Turunannya
Sumber Hukum dalam manajemen islam yang pertama adalah Al-Qur'an. Al-Qur'an secara etimologis adalah bentuk mashdar dari kata qa-ra-a yang artinya "bacaan”. Al-Qur'an adalah wahyu kalam Allah SWT yang diturunkan melalui Rasulullah SAW yang disampaikan kepada Umat Manusia dalam rangka menuntun kehidupan di dunia. Al-Qur'an menurut departemen agama RI terdiri dari 30 Juz, 114 Surat, 6.236 Ayat, dan 324.345 Huruf (Depag RI, 1989).

b. Fungsi Al-Qur'an

Dilihat dari isinya, al-qur'an mempunyai fungsi namun dapat dirangkum menjadi 2 fungsi (Syarifuddin, 1997). Pertama sebagai "rahmat" yang dikaruniakan Allah kepada Manusia bila mereka menerima dan mengamalkan keseluruhan isi al-qur'an, maka akan mendapatkan kehidupan yang bahagia didunia dan kesenangan hidup diakhirat. Kedua, sebagai "hudan" atau petunjuk kata petunjuk mengandung arti luas yang berarti petunjuk bagi manusia untuk mengenal Rasul dan membuktikan 
kebenaran sekaligus menjadi tanda atau identitas kerasulan.

As-Sunnah

As-Sunnah secara harfia berarti bicara, adat istiadat, kebiasaaan hidup yang mengacuh kepada perilaku Nabi SAW yang di jadikan teladan. Sunnah dalam istilah ulama ushul adalah : “Apa-apa yang di riwayatkan dari Nabi Muhammad SAW, baik dalam bentuk ucapan, perbuatan, maupun pengakuan dan sifat Nabi" (Syarifuddin, 1997). Sedangkan sunnah dalam istilah ulama fikih adalah : "sifat hukum bagi suatu perbuatan yang di tuntuk melakukannya dalam bentuk tuntutan yang tidak pasti” dengan pengertian di beri pahala orang yang melakukannya dan tidak berdosa orang yang tidak melakukannya.

\section{Pandangan Islam tentang Perkreditan}

Praktik pelaksanaannya sistem perkreditan yang dianut oleh dunia internasional saat ini mengacu pada sistem bunga dalam prose pembayarannya. Maka perspektif islam terhadap perkreditan yang dilakukan masyarakat luas saat ini, islam memandangnya menjadi 2 pendapat: pendapat pertama mengatakan boleh, pendapat kedua mengharamkan, hal itu bergantung pada beberapa faktor seperti dalam penjelesan berikut:

$$
\text { Berdasarkan bukunya yang }
$$

berjudul Hukum Islam dan Transformasi Pemikiran karangan Prof. Dr. H. Umar Shihab dijelaskan bahwa bunga bank yang dipungut dan diberikan kepada nasabah jauh lebih kecil dibandingkan dengan jumlah bunga atau riba yang diperlakukan pada masa jahiliyyah. Sementara pemungut riba waktu itu selalu mendapat keuntungan besar karena melipat gandakan pembayaran. Sekarang ini pemungutan bunga bank tidak akan membuat bank dan nasabah itu sendiri memperoleh keuntungan besar dan sebaliknya bank dan nasabah samasama tidak dirugikan atas adanya bunga tersebut. Oleh sebab itu tidak sepantasnya bunga bank diharamkan. Sebab meskipun diidentikkan dengan riba, namun tujuan dan metode pelaksanaannya sama sekali jauh dari yang pernah dipraktekkan di jahiliyyah yang diharamkan dalam al-Quran itu, dan bunga bank lebih tepat dianalogikan dengan jual beli yang didasari atas suka sama suka.

Berdasarkan ketetapan ulama hasil lokakarya tanggal 19-22 Agustus 
di bogor bahwa bunga bank sepanjang dipergunakan dalam kondisi darurat dan kepentingan umum, maka status hukumnya adalah mubah, tetapi jika syarat yang diajukan tersebut tidak terpenuhi, maka bunga bank secara otomatis berstatus hukum haram.

Terlepas dari pro kontra pandangan umat islam terhadap kredit serta suku bunga didalamnya, maka penulis berpendapat bahwa sistem kredit yang dilakukan oleh perbankan dan lembaga keungan lainnya diperbolehkan, namun dalam pelaksanaanya kredit yang diharamkan apabila kredit yang didalamnya terdapat suku bunga/riba maka haram hukumnya.

Hal tersebut diperkuat dengan adanya penjelasan dalam Al-Qur'an dan Hadist yang dikemukakan oleh Syaikh Muhammad bin Shalih Al-Utsaimin berkata [dalam Fatawa Mu'ashirah: 5253, dari Fatwa Syaikh Ibnu Utsaimin] : "Menjual dengan kredit artinya bahwa seseorang menjual sesuatu (barang) dengan harga tangguh yang dilunasi secara berjangka. Hukum asalnya adalah dibolehkan berdasarkan firman Allah swt: "Hai orang-orang yang beriman, apabila kamu bermu'amalah tidak secara tunai untuk waktu yang ditentukan, hendaklah kamu menuliskannya" [QS. Al-Baqarah: 282]. Demikian pula, karena Nabi Muhammad SAW membolehkan jual beli As-Salam, yaitu membeli secara kredit terhadap barang yang dijual.

Al-Qur'an menjelaskan dalam beberapa ayat bahwa riba haram hukumnya. Ayat-ayat yang menjelaskan tentang keharaman riba sebagai berikut:

1. QS. ar-Rum: 39, yang terjemahnya 'Dan sesuatu riba (tambahan) yang kamu berikan agar dia menambah pada harta manusia, maka riba itu tidak menambah pada sisi Allah...'

2. QS. an-Nisa' yang mengisyaratkan keharamannya, yang terjemahnya "Dan disebabkan mereka memakan riba, padahal sesungguhnya mereka telah dilarang daripadanya dan karena mereka memakan harta orang lain secara batil..."

3. QS. Ali Imran: 130, yang terjemahnya "Hai orang-orang yang beriman, janganlah kamu memakan riba dengan berlipat ganda dan bertakwalah kamu kepada Allah supaya kamu mendapat keberuntungan" 
4. Pada tahap terakhir, riba orang yang beriman”.(QS. Al-Baqarah: diharamkan secara total dalam 278).

berbagai bentuknya. Allah swt. Sedangkan fasilitas kredit itu berfirman dalam QS. Al-Baqarah: sendiri hukumnya tergantung dari 278, yang berbunyi "Hai orang- bagaimana anatomi sistemnya. Bila orang yang beriman, bertakwalah masih terdapat unsur bunga ribawi, kepada Allah dan tinggalkanlah sisa maka menjadi haram.Sedangkan bila riba (yang belum dipungut) jika murni akad kredit yang syar'i, maka kamu orang-orang yang beriman.” hukumnya halal.

Inilah ayat paling klimaks tentang Kredit dibolehkan dalam hukum pengharaman riba dalam berbagai jual beli secara Islami. Kredit adalah bentuknya. Berdasarkan ayat tersebut, membeli barang dengan harga yang bunga bank merupakan salah satu berbeda antara pembayaran dalam bentuk riba, sehingga baik sedikit bentuk tunai tunai dengan bila dengan maupun banyak tetap berhukum haram. tenggang waktu. Ini dikenal dengan Hukum Perkreditan Menurut istilah: bai bit taqshid atau bai`bitsEkonomi Islam

Bunga adalah hal yang telah tsaman ‘ajil. Gambaran umumnya adalah penjual dan pembeli sepakat disepakati keharamannya oleh semua lapis umat Islam. Sebab bunga itu dengan mudah bisa dibedakan dengan jual beli yang halal. Betapapun kecil bunga yang dikenakan, tetaplah Allah SWT telah mengharamkannya. Sebab keberadaan bunga itu memang wujud bertransaksi atas suatu barang (x) dengan harga yang sudah dipastikan nilainya (y) dengan masa pembayaran (pelunasan) (z) bulan.Harga harus disepakati di awal transaksi meskipun pelunasannya dilakukan kemudian.

Ada sementara pendapat yang dari riba itu sendiri, yang di dalam Almengatakan bahwa bila si penjual itu Quran telah disebutkan harus menaikkan harga karena temponya, ditinggalkan sekecil-kecilnya. "Hai sebagaimana yang kini biasa dilakukan orang-orang yang beriman, oleh para pedagang yang menjual bertakwalah kepada Allah dan dengan kredit, maka haram hukumnya tinggalkan sisa riba jika kamu orang- dengan dasar bahwa tambahan harga itu 
berhubung masalah waktu dan itu sama dengan riba.

Jumhur ulama membolehkan jual beli kredit ini, karena pada asalnya boleh dan nash yang mengharamkannya tidak ada. Jual beli kredit tidak bisa dipersamakan dengan riba dari segi manapun. Oleh karena itu seorang pedagang boleh menaikkan harga menurut yang pantas, selama tidak sampai kepada batas pemerkosaan dan kezaliman.Kalau sampai terjadi demikian, maka jelas hukumnya haram.

Imam Syaukani berkata: "Ulama Syafi'iyah, Hanafiyah, Zaid bin Ali, alMuayyid billah dan Jumhur berpendapat boleh berdasar umumnya dalil yang menetapkan boleh. Dan inilah yang kiranya lebih tepat."

\section{KESIMPULAN}

Berdasarkan uraian di atas maka penulis dapat simpulkan bahwa hukum dari kredit itu sendiri dibolehkan, tergantung dari bagaimana anatomi sistemnya. Bila masih terdapat unsur bunga ribawi, maka menjadi haram. Sedangkan bila murni akad kredit yang syar' $i$, maka hukumnya halal, seperti yang telah dijelaskan sebelumnya.

Jumhur ulama membolehkan jual beli bila si penjual itu menaikkan harga karena temponya, karena pada asalnya boleh dan nash yang mengharamkannya tidak ada. Jual beli kredit tidak bisa dipersamakan dengan riba dari segi manapun. Oleh karena itu, seorang pedagang boleh menaikkan harga, selama tidak sampai kepada batas berlebihan atau kedzaliman. Kalau sampai terjadi demikian, maka jelas hukumnya haram.

\section{DAFTAR PUSTAKA}

Abadi, A.L. 2003. Ilmu Penyakit Tumbuhan I. Malang: Bayu Media.

Abdul, Kadir Muhammad. 2000. Hukum Perdata Indonesia. Bandung: citra Aditya Bakti.

Ali, As-Shabuni Muhammad. 1998. Hukum Waris dalam Syariat Islam. Bandung: CV. Dipenegoro.

Antonio, Muhammad Syafi'i. 2001. Bank Syariah dari Teori ke Praktik. Jakarta: Gema Insani Press.

Departemen Agama RI. 1989. Al Qur'an dan Terjemahannya. Semarang: Al Waah. Djazulli, A. dan Yadi Janwari. 2002. Lembaga-Lembaga Perekonomian Umat (Sebuah Pengenalan). Fajar Interpratama Offset: PT Raja Grafindo Persada. 
Hakim, Lukman. 2012. Prinsip-Prinsip Ekonomi Islam. PT Gelora Aksara Pratama, Erlangga.

Al-Jaziri, Abd Arrahman. 1972. Kitab Al-Fiqih Ala Al-Mazahib Al-Arba'ah. Beirut: Dar al-Fikr.

Al-Jurjawi, Syaikh 'Ali Ahmad. 1994. Hikmah Dibalik Hukum Islam. Buku 1. Mustaqiim.

Karim, Adiwarman Azwar. 2004. Sejarah Pemikiran Ekonomi Islam. Kharisma Putra Uama Offset. PT Rajagrafindo Persada.

Nasution. 1996. Manajemen Transportasi. Jakarta: Ghalia Indonesia.

Rofi'uddin, Ahmad dan Darmiyati Zuhdi. 1998. Pendidikan Bahasa dan Sastra Indonesia di Kelas Tinggi. Jakarta: Depdikbud.

Suyatno, Thomas, dkk. 1997. Dasar-Dasar Perkreditan. Jakarta: Gramedia Pustaka Utama.

Syarifuddin, Amir. 1997. Ushul Fiqih Jilid I. Jakarta: Logos Wacana Ilmu. 